\title{
Food in a time of COVID-19
}

\author{
Disease is often said to be a great leveller, striking the rich and poor alike. However, the COVID-19 pandemic has \\ thrown into stark contrast the inequalities inherent in our food systems.
}

\section{T} he United Nations World Food Programme estimates that the disruptions caused by COVID-19 may double the number of people facing starvation around the world to nearly a quarter of a billion ${ }^{1}$. Most have already been affected by conflicts and previous food crises, such as those in 2007-2008 that affected millions in developing countries. But the pandemic is causing havoc on an international scale, with interlinking variables and cascading layers confounding simple solutions.

Despite governments trying to keep their citizens afloat with economic assistance, the 'lockdowns' have exposed deficiencies in food systems that were already barely coping, even in some of the richest countries on earth. New York City kept its school system open as long as it could, not for educational purposes but to support around 200,000 children whose school provides their one full, nutritious meal each day; worldwide, some 368 million children are now missing out on such meals ${ }^{2}$. The US Department of Agriculture has promised to send boxes of shelf-stable foods to offset this loss, but this looks like a version of an earlier program (see ref. ${ }^{3}$ ) that remains underfunded and under-nutritious ${ }^{4}$.

Food banks across the US are struggling to meet overwhelming demands as unemployment has surged ${ }^{5}$, and in the UK, 1.5 million people have reported going without food for over a day in the past month, unable to pay for food despite repeated promises from the government to make up lost wages ${ }^{6}$. Protests, looting and even riots have been reported across the Global South, whose more labour-intensive food systems face a 'double whammy' of lost wages and lost production. COVID-19-related hunger may well kill more people than direct infection.

However, there is no actual shortage of food, rather a failure of logistics and systems. The overnight drops in demand for wholesale supply to restaurants and other food preparation businesses have caused a staggering level of food wastage. The New York Times reported that one farmer in Idaho buried one million pounds of produce; others are ploughing back fields of unharvested beans while millions of gallons of milk - equivalent to $5 \%$ of US daily production — are being discarded into ditches ${ }^{7}$. Although stricken producers may want to provide food to those who need it, the economics of transporting, packaging and storing food in our current industrial system make it impossible.

For the skilled workers upon whom so many harvests depend, the increased stringencies of border controls have made crossing national lines a harrowing and prohibitive experience. In Europe, French farms put out calls for unemployed urban workers to help in the fields, only to find those who answered quickly leaving; the UK's 'Pick for Britain' campaign tried to recruit 70,000 Britons for harvests and farm work, but the response was so meagre that special planes have been chartered to fly in Romanian farmworkers ${ }^{8}$. Ironically, these workers were applauded on the front pages of the same newspapers who used fears of Eastern European immigration to make the case for Brexit. President Trump's 23 April announcement of an immediate halt to all immigration in the US quickly, and quietly, exempted migrant farmworkers ${ }^{9}$.

Food safety issues in our industrial agriculture system ${ }^{10}$ apply as equally to workers as to crops. Labourers in farms and production facilities work side-by-side for hours on end, and must be given improved protective equipment and working conditions. The alternative is an outbreak like that in South Dakota, where half of the population in a single town of 438 people have tested positive, all of whom worked at one 3,700-worker facility ${ }^{11}$.

Until a vaccine can be developed, further waves of this virus will make lessons learned in recent months all the more important to proof our food systems against future lockdowns and uncertainties. Food banks may take up some slack, but they are no permanent solution. As a leading critic of the 'hunger industrial complex' points out, food banks in the US work hand-in-hand with the companies that benefit most from keeping wages low in the first place for millions now standing in food queues ${ }^{12}$.

Although countries like France have made assurances that financial help will be available, many small businesses are facing bankruptcy, including markets, artisanal food companies and restaurants. These latter will have to reduce seating and increase costs for safety reasons even when they are able to reopen. Ultimately, the diversity of what, how and with whom we eat will be reduced. "I started my restaurant as a place for people to talk to one another," one restauranteur told The New York Times, "with a very decent but affordable glass of wine and an expertly prepared plate of simply braised lamb shoulder on the table to keep the conversation flowing"; she is closing down her establishment of 20 years in New York City's East Village ${ }^{13}$.

And yet there are reasons to hope that a new paradigm of 'food sovereignty' may arise in the wake of the pandemic ${ }^{14}$. Community gardens have seen a surge in volunteers, and while supermarkets in many countries report a shortage of flour, small and independent mills have seen business boom following a surge in home baking ${ }^{15}$.

Food economists have been warning for years that global, 'just-in-time' food delivery chains were inherently at risk of failing. Perhaps a shift to a more decentralized food system would provide the security that farmers, small businesses, workers, customers and the starving of the world desperately need. No one wished for this pandemic, but let's not waste the lessons it can teach us.

Published online: 15 May 2020 https://doi.org/10.1038/s41477-020-0682-7

References

1. COVID-19 will double number of people facing food crises unless swift action is taken. World Food Programme https://bit. ly/2W3QpfJ (2020).

2. Dahir, A. L. 'Instead of coronavirus, the hunger will kill us.' A global food crisis looms. The New York Times https://nyti. $\mathrm{ms} / 2 \mathrm{~W} 6 \mathrm{NnHL}$ (2020).

3. Nat. Plants 4, 189 (2018).

4. Stieb, M. The USDA's plan to feed Americans and pay farmers is not enough. Intelligencer https://nym.ag/3aZanwA (2020).

5. Kulish, $\mathrm{N}$. 'Never seen anything like it': cars line up for miles at food banks. The New York Times https://nyti.ms/2SELC2j (2020).

6. Lawrence, F. UK hunger crisis: $1.5 \mathrm{~m}$ people go whole day without food. The Guardian https://bit.ly/3dmNaWN (2020).

7. Yaffe-Bellany, D. \& Corkery, M. Dumped milk, smashed eggs, plowed vegetables: food waste of the pandemic. The New York Times https://nyti.ms/3c45QdG (2020).

8. Kostov, N. Meichtry, S. \& Pancevski, B. 'The French are very bad at picking asparagus.' Virus imperils European farming. The Wall Street Journal https://on.wsj.com/3b2CV81 (2020).

9. Crampton, L. Farm workers to be exempt from Trump's immigration ban. Politico https://politi.co/3chZpU8 (2020).

10. Nat. Plants 5, 241 (2019).

11. Huber, M. Smithfield Foods to close Sioux Falls plant indefinitely amid COVID-19 outbreak. Argus Leader https://bit.ly/2YzFmg 1 (2020).

12. Fisher, A. The COVID crisis is reinforcing the hunger industrial complex. The MIT Press Reader https://bit.ly/2ywx9lv (2020).

13. My restaurant was my life for 20 years. Does the world need it anymore? New York Times Magazine https://nyti.ms/3dg1Kzc (2020).

14. Brimm, K. The moment for food sovereignty is now. Civil Eats https://bit.ly/3b7wXTC (2020).

15. Halloran, A. flour shortage? Amber waves of regional grains to the rescue. Civil Eats https://bit.ly/2zbDWxP (2020). 